\title{
The Influence of Organizational Commitment, Transformational Leadership and Work Motivation through OCB on Performance in The Pratama Tax Office Jakarta Kalideres
}

\author{
Cicilia Eritawanti Widjilestari ${ }^{1}$, Farida Elmi $^{2}$ \\ \{cicilia.eritawanti@gmail.com¹, faridaelmi57@gmail.com² ${ }^{2}$.g. \\ Universitas Mercubuana, Jakarta, Indonesia ${ }^{12}$
}

\begin{abstract}
Realization of tax acceptance as one of the main performance indicators (IKU) Tax Office (KPP) is very important in supporting state financing. Year 2017 and 2018 KPP Pratama Jakarta Kalideres can reach the realization of acceptance which is the target of $118.48 \%$ and $139.33 \%$. In the year 2019 the realization of acceptance did not reach the target of $96.52 \%$. From the results of the factor-factor studies that have not achieved the achievement of target acceptance is the organizational commitment (X1), transformational Leadership (X2) and Motivation (X3) through organizational citizenship behavior (OCB) (Y1) to Performance (Y2). The number of samples in this study was all KPP employees totaling 102 people. Data collection techniques are through internal data collection, interviews and questionnaires. Data analysis techniques using track analysis with SmartPLS processing software (Partial Least Square). The results of the hypothesis testing showed that: 1) the organizational commitments positively and significantly affect the OCB; 2) Transformational leadership is positively and significantly influential against OCB; 3) The motivation of positive and significant influence on OCB; 4) Organizational commitments have a positive and significant impact on performance; 5) Transformational leadership has a positive and significant influence on performance; 6 ) The motivation has a positive and significant influence on performance; 7) OCB has a positive and significant influence on performance; 8) The organizational commitment indirectly proves the influence of performance through $\mathrm{OCB}$; 9) The transformational leadership indirectly also proves the influence of performance through OCB; 10) Indirect motivation also proves the influence of performance through OCB. The study concluded that an increase through understanding of organizational commitments, transformational leadership, and motivation would affect the OCB of employees who would influence improving KPP's performance. The results of this research can be a reference for the organization to understand the variables that affect the OCB as a material of study and evaluation for performance enhancement.
\end{abstract}

Keywords: organizational commitments, transformational leadership, motivation, Organizational Citizenship behavior, performance

\section{Introduction}

One of the main performance indicators of the Tax Office (KPP) is the realization of tax revenue. Achievement of Tax Revenue at KPP Pratama Jakarta Kalideres for the 2017 s.d. 
2019 amounted to $118.48 \%, 139.33 \%$ and $96.52 \%$. Not achieving the revenue target in 2019 is based on the results of an interview with the Head of the Jakarta Kalideres KPP Pratama Office, that to achieve the target which is always increasing every year requires cooperation and synergy from all employees of KPP Pratama Jakarta Kalideres, apart from commitment to organization, guidance and supervision from supervisors and the motivation of the employees concerned.

From the pre-survey results that the variables that affect performance are organizational commitment, transformational leadership, motivation through Organizational Citizenship Behavior. Based on research conducted by Maharani et al at PT Bank Syariah Mandiri Malang, East Java, that OCB does not mediate transformational leadership on performance. From the results of the pre-survey and research gap, we will carry out the research process at KPP Pratama Jakarta Kalideres with the title "The Influence of Organizational Commitment, Transformational Leadership and Work Motivation Through Organizational Citizenship Behaviors on Performance In The Pratama Tax Office, Jakarta Kalideres".

Based on the background and problem identification, the purpose of this research is to identify and analyze; 1) The influence of organizational commitment on employee OCB at KPP Pratama Jakarta Kalideres; 2) The influence of transformational leadership on employee OCB at KPP Pratama Jakarta Kalideres; 3) The influence of work motivation on employee OCB at KPP Pratama Jakarta Kalideres; 4) The influence of organizational commitment on performance at KPP Pratama Jakarta Kalideres; 5) The influence of transformational leadership on performance at KPP Pratama Jakarta Kalideres; 6) The influence of motivation on performance at KPP Pratama Jakarta Kalideres; 7) The influence of employee OCB on the performance of KPP Pratama Jakarta Kalideres; 8) The influence of organizational commitment on the performance of KPP Pratama Jakarta Kalideres with OCB as the mediation; 9) The influence of transformational leadership on the performance of KPP Pratama Jakarta Kalideres with OCB as mediation; 10) The influence of work motivation on the performance of KPP Pratama Jakarta Kalideres with OCB as the mediation.

\subsection{Theoretical Background \\ 1.1.1 Performance}

Gary Dessler (2015: 13) suggests that performance means the willingness of a person or group of people to carry out activities and improve them according to their responsibilities with results as expected. The basis for measuring the performance of DGT employees is described in the main Performance Indicators (IKU) in accordance with the Minister of Finance Decree number KMK-467 / KMK.01 / 2014 concerning the Performance Management within the Ministry of Finance as amended by KMK number 556 / KMK.01 / 2015. Employee performance appraisal is carried out by measuring the Employee Performance Value (NKP) which comes from the KPI achievements as the basis for achieving the organization's strategic goals set out in the balance scorecard (BSC) and the Value of Behavior (NP).

\subsubsection{Organizational Citizenship Behavior}

According to Robbins and Judge (2017: 40) defines OCB as a choice behavior that is not part of an employee's formal work obligations but supports the influence functioning of the organization. In the world of organization, the OCB behavior of an employee is a very important element of an employee's attitude towards his job. OCB is an extra behavior that can be used as evaluation material which can have a special influence on the organization and the achievement of organizational inoffensiveness. 


\subsubsection{Organizational Commitment}

According to Jex and Thomas (2008) in Kaswan (2015: 125), the definition of organizational commitment is as follows: Organizational commitment can be considered as the level of employee dedication to the organization where he works and the willingness to work on behalf of / for the benefit of the organization, and the possibility of maintaining his membership. Based on this definition, it can be interpreted that organizational commitment in the business world is the level of employee loyalty to the organization.

\subsubsection{Transformational Leadership}

According to Bass (1985) in the book Yukl (2013, p. 313) explains that transformational leadership is a condition in which the followers of a transformational leader feel that there is trust, admiration, loyalty, and respect for the leader, and they are motivated to do more than at first, they expected. Transformational leadership is concerned with strong selfidentification, the creation of a shared vision for the future and the relationship between leaders and followers based on one thing that is more than rewarding for obedience. The transformational leader defines the need for change, creates a new vision, mobilizes commitment to live the vision and transforms followers both individually and in teams.

\subsubsection{Motivation}

Steers and Porter (2015: 33) argue that: "Work motivation is an effort that can lead to behavior, direct behavior, and maintain or maintain behavior in accordance with the work environment in the organization". According to Gitosudarmo (2015: 109) motivation is a factor that encourages someone to do a certain activity, therefore motivation is often interpreted as a driving factor for one's behavior. Based on this opinion, employee motivation is an inner drive that drives and controls and influences their willingness to work.

\subsubsection{Research Framework}

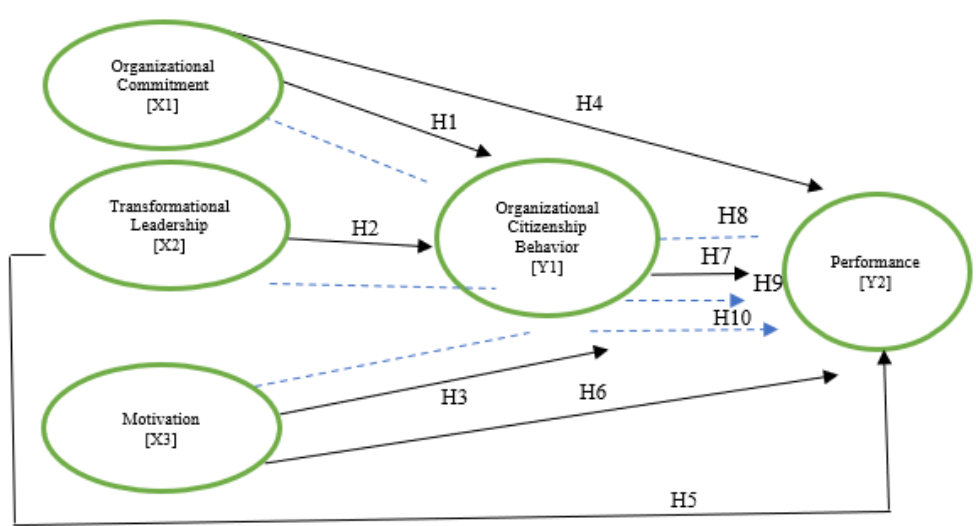

Fig 1. Research Framework

\subsection{Hypothesis}

Based on the research objectives and theoretical basis and problem formulation previously described, the hypothesis proposed in this research is as follows: 
H1. Is there an influence of organizational commitment on employee OCB at KPP Pratama Jakarta Kalideres?

$\mathrm{H} 2$. Is there an influence of transformational leadership on employee OCB at KPP Pratama Jakarta Kalideres?

H3. Is there an influence of work motivation on employee OCB at KPP Pratama Jakarta Kalideres?

H4. Is there an influence of organizational commitment on performance at KPP Pratama Jakarta Kalideres?

H5. Is there an influence of transformational leadership on performance at KPP Pratama Jakarta Kalideres?

H6. Is there an influence of work motivation on performance at KPP Pratama Jakarta Kalideres?

H7. Is there an influence of employee OCB on the performance of KPP Pratama Jakarta Kalideres?

H8. Is there an influence of organizational commitment to the performance of KPP Pratama Jakarta Kalideres with OCB as the mediation?

H9. Is there an influence of transformational leadership in the performance of KPP Pratama Jakarta Kalideres with OCB as mediation?

H10. Is there an influence of work motivation on the performance of KPP Pratama Jakarta Kalideres with OCB as the mediation?

\section{Research Method}

This research is descriptive quantitative research with a causality research approach between the independent variable and the dependent variable. The dependent variable in this study is Organizational Citizenship Behavior (Y1) and performance (Y2). The independent variables are organizational commitment (X1), transformational leadership (X2) and work motivation (X3). In order to avoid different definitions of the variables used in this study, it is necessary to make a definition or definition of each variable as follows:

Table 1. The operational definition of a variable

\begin{tabular}{|c|c|}
\hline Variable & Dimension \\
\hline Organizational Commitment (X1) & 1. Affective Commitment \\
\hline \multirow[t]{2}{*}{ Mayer and Allen in Luthan (2011) } & 2. Continued Commitment \\
\hline & 3. Normative Commitment \\
\hline Transformational Leadership (X2) & 1. Idealized influence \\
\hline \multirow[t]{3}{*}{ Bass and Avolio (1985) in Yukl $(2013 ; 313)$} & 2. Inspirational motivation \\
\hline & 3. Intellectual simulation \\
\hline & 4. Individualized consideration \\
\hline \multirow{3}{*}{$\begin{array}{l}\text { Motivation (X3) } \\
\text { McClelland (in Latif and Latief, 2018:115) }\end{array}$} & 1. Need for achievement \\
\hline & 2. Need for Power \\
\hline & 3. Need for Affiliation \\
\hline \multirow{3}{*}{$\begin{array}{l}\text { Organizational Citizenship Behavior (Y1) } \\
\text { Organ (Kaswan, 2015:84) }\end{array}$} & 1. Sportsmanship \\
\hline & 2. Altruism \\
\hline & 3. Civic virtue \\
\hline
\end{tabular}




\begin{tabular}{ll} 
& 4. Courtesy \\
\hline Performance (Y2) & 1. Quantity of work \\
\cline { 2 - 2 } KMK-556/KMK.01/2015 Performance & 2. Quality of work \\
\cline { 2 - 2 } Management within the Ministry of Finance & 3. Individual values \\
\hline
\end{tabular}

\subsection{Sample and Population}

The population in this study was all employees who worked at KPP Pratama Jakarta Kalideres with a total of 102 employees. The sampling technique used in this study is a saturated or census sampling technique. So that the sample used in this study were all populations, as many as 102 people as respondents.

\subsection{Data Analysis Method}

The author uses descriptive statistics to establish a table of frequency distribution to determine whether the rate of value (score) entered the study variables in categories: very low, low, medium, high, and very high. In this study the data analysis was processed using SmartPLS (Partial Least Square).

\subsection{Evaluation of Measurement Model (Outer Model)}

a. Convergent Validity

Convergent validity wants to confirm construct measurements. The rule of thumb that is usually used to assess factor loading must be greater than 0.7 (Latan and Ghozali, $87: 2014)$

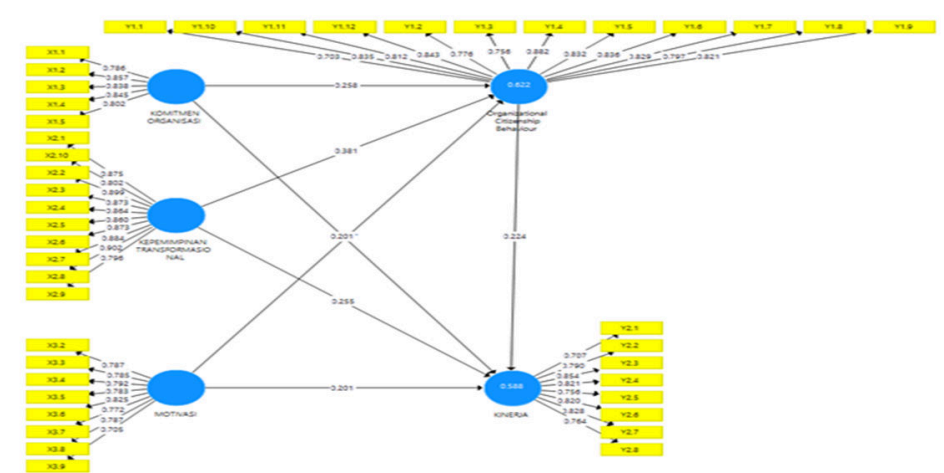

Fig 2. Construct Outer Model

Based on Figure 2, all instrument / item values are above 0.7 so that it can be said to be valid.

b. Reliability Test (Composite Reliability and Cronbach's Alpha)

To measure reliability with the Composite Reliability and Cronbach Alpa $(\alpha)$ statistical test. A variable is said to be reliable if it provides $\alpha>0.70$. The results can be seen in the following table:

Tabel 3. Reliability Test

\begin{tabular}{cccc}
\hline Variabel & $\begin{array}{c}\text { Cronbach's } \\
\text { Alpha }\end{array}$ & $\begin{array}{c}\text { Composite } \\
\text { Reliability }\end{array}$ & Result \\
\hline Organizational Commitment & 0.884 & 0.915 & Reliable
\end{tabular}




\begin{tabular}{llll} 
Transformational Leadership & 0.962 & 0.967 & Reliable \\
Motivation & 0.908 & 0.926 & Reliable \\
$O C B$ & 0.952 & 0.958 & Reliable \\
Performance & 0.916 & 0.931 & Reliable \\
\hline
\end{tabular}

Resources: Output SmartPLS 3.3.2, 2020

\subsection{Structural Model Evaluation / Hypothesis Test (Inner Model)}

\subsubsection{R-Square Test}

The R-Square score in PLS can be used to explain an influence of certain exogenous latent variables on endogenous latent variables (Ghozali and Latan, 2017:91).

Tabel 4. R-Square Score

\begin{tabular}{ll}
\hline Variable & R Square \\
\hline Performance & 0.588 \\
\hline OCB & 0.622 \\
\hline Resources: Output SmartPLS 3.3.2, 2020
\end{tabular}

The results of the R-square test show that the R-square value for the Performance variable (Y2) is 0.588 and the OCB (Y1) variable is 0.622 which has a value above 0.33 and below 0.67 , so it can be said that the structural model is moderate.

\subsubsection{Goodness of Fit Model}

The Goodness of Fit structural model on the inner model uses the predictive-relevance (Q-square) value. The Q-square value is greater than zero $(0)$ indicating that the model has a predictive relevance value. The predictive relevance value can be calculated by the formula:

$$
\begin{aligned}
& \mathrm{Q} 2=1-(1-\mathrm{R} 1)(1-\mathrm{Rp}) \\
& \mathrm{Q} 2=1-(1-0.588)(1-0.622) \\
& \mathrm{Q} 2=0.844
\end{aligned}
$$

The Q-square calculation above, the predictive-relevance value is $0.844(>0)$, which means that $84.4 \%$ of the variation in the OCB and performance variables is explained by the variables used. Thus, the model is said to have a relevant predictive value.

\subsection{Hypothesis Test (Path Coefficient)}

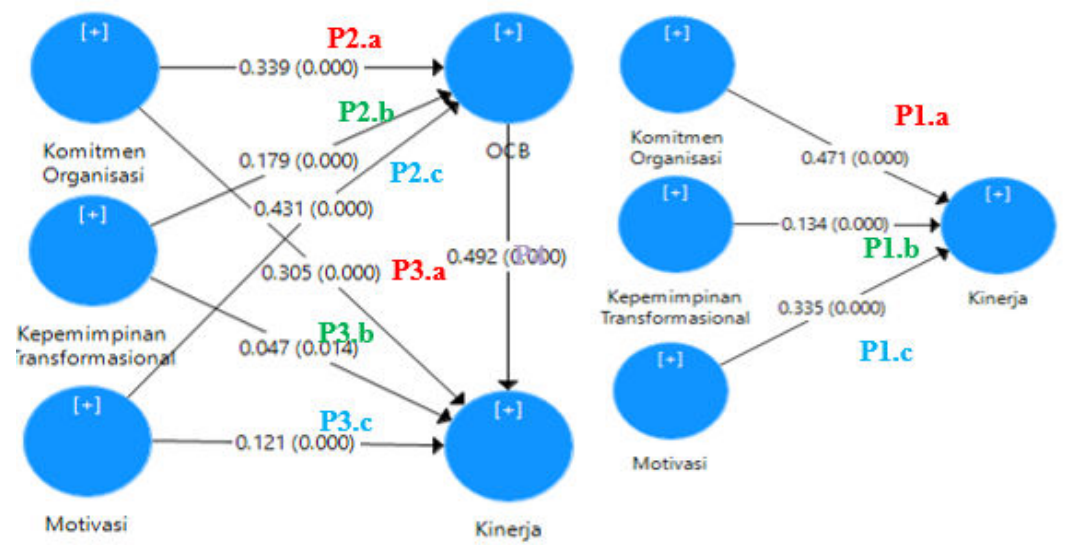

Fig 3. Indirect Influence Model 1 and 2 


\section{Results and Discussion}

\subsection{The Influence of Organizational Commitment (X1) on OCB (Y1)}

Organizational commitment has an influence of 0.339 on OCB because it has a T-statistic value $(17,701)$ that is higher than the t-table 1,984 and a $p$-value below the alpha value of $0.05(5 \%)$, namely 0,000 ; Or it can be said that Organizational Commitment has a positive and significant influence on OCB so that it can be concluded that hypothesis 1 is accepted. The results of this study are consistent with the results of research from Netra Gunawan (2017) showing that Organizational Commitment has a positive and significant influence on OCB employees in PT. BPR ASHI.

\subsection{The Influence of Transformational Leadership (X2) on OCB (Y1)}

Transformational leadership has an influence of 0.179 on OCB because it has a T-statistic value (9.454) which is higher than the t-table 1.984 and a p-value below the alpha value of $0.05(5 \%)$, namely 0.000 ; or it can be said that transformational leadership has a positive and significant influence on OCB so that it can be concluded that hypothesis 2 is accepted. The results of this study are consistent with the results of research from Vipraprastha, et al (2018) showing that Transformational Leadership has a positive and significant influence on OCB PT Sarana Arga Gemeh Amerta in Denpasar City.

\subsection{The Influence of Motivation (X3) on OCB (Y1)}

Motivation has an influence of 0.431 on OCB because it has a T-statistic value $(22,727)$ that is higher than the t-table 1.984 and a p-value below the alpha value of $0.05(5 \%)$, namely 0,000 ; or it can be said that work motivation has a positive and significant influence on OCB so that it can be concluded that hypothesis 3 is accepted. This is also in line with research by Al-Mahasneh (2015) which shows that work motivation has a positive influence on OCB.

\subsection{The Influence of Organizational Commitment (X1) on Performance (Y2)}

Organizational commitment has an influence of 0.305 on performance because it has a Tstatistic value (13.715) which is higher than t-table 1.984 and a p-value below an alpha value of $0.05(5 \%)$, namely 0.000 ; Or it can be said that Organizational Commitment has a positive and significant influence on performance so that it can be concluded that hypothesis 4 is accepted. The results of this study are in line with the results of research from Andrew (2017) showing that Organizational Commitment has a positive influence on employee performance.

\subsection{The Influence Transformational Leadership (X2) on Performance (Y2)}

Transformational leadership has an influence of 0.047 on performance because it has a Tstatistic value (2.473) which is higher than the $\mathrm{t}$-table 1.984 and a $\mathrm{p}$-value below the alpha value of $0.05(5 \%)$, namely 0.020 ; or it can be said that Transformational Leadership has a positive and significant influence on performance so that it can be concluded that hypothesis 5 is accepted. The results of this study are in line with the results of Grace Akoth Dola's (2015) study showing that transformational leadership positively affects employee performance.

\subsection{The Influence of Motivation (X3) on Performance (Y2)}

Work motivation has an influence of 0.121 on performance because it has a T-statistic value (4.805) which is higher than the t-table 1.984 and a $p$-value below the alpha value of 
0.05 (5\%), namely 0.000 ; or it can be said that work motivation has a positive and significant influence on performance so that it can be concluded that hypothesis 6 is accepted. This is also in line with research by Kehinde Adebayo (2015) showing that there is a positive influence on work motivation and leadership on employee performance.

\subsection{The Influence of OCB (Y1) on Performance (Y2)}

OCB has an influence of 0.492 on performance because it has a T-statistic value $(16,755)$ which is higher than t-table 1,984 and a p-value below an alpha value of $0.05(5 \%)$, namely 0,000 ; or it can be said that OCB has a positive and significant influence on performance so that it can be concluded that hypothesis 7 is accepted. This is also in line with research by Chelagat, et al (2015) which shows that there is a positive influence of OCB on performance.

\subsection{The Influence of Organizational Commitment (X1) on Performance (Y2) with OCB (Y1) as a mediating variable}

Tables 5 and 6 on lines P2, a, P3.a and P1.a show that organizational commitment has a positive and significant influence on OCB (path P2.a "0.339"), the influence of direct organizational commitment on performance by involving the OCB variable gets the best results. Significant (path P3.a "0.305") and while the influence of direct organizational commitment on performance without involving OCB variables got significant results (path P1.a "0.471"), with a larger path coefficient value. The mediating nature of OCB to the relationship between direct organizational commitment to performance is a partial mediating variable. So, it can be concluded that hypothesis 8 is accepted. This research can complement the research conducted by Khan (2016), which states that employee performance is not significantly affected by an organizational commitment to the public sector.

\subsection{The Influence of Transformational Leadership (X2) on Performance (Y2) with OCB (Y1) as a mediating variable}

Tables 5 and 6 on lines P2, b, P3.b and P1.b show that transformational leadership has a positive and significant influence on OCB (line P2.b "0.179"), OCB has a positive and significant influence on performance (path $\mathrm{P} 4$ ), the influence of direct transformational leadership on performance by involving OCB variables got significant results (path P3.b "0.047"), while the influence of direct transformational leadership on performance without involving OCB variables got significant results (path P1.b "0.134"), with a larger path coefficient value. That is, the mediating nature of OCB on the relationship between direct transformational leadership and performance is a partial mediating variable. So, it can be concluded that hypothesis 9 is accepted. This study is not in accordance with research conducted by Maharani et al (2015), who found that OCB does not mediate transformational leadership on performance at PT Bank Syariah Mandiri Malang, East Java.

\subsection{The Influence of Motivation (X3) on Performance (Y2) with OCB (Y1) as a mediating variable}

Hypothesis testing by including and without including the OCB variable as a mediating variable in the influence of work motivation on performance is presented in Tables 5 and 6. Work motivation has a positive and significant influence on OCB (path P2.b), OCB has a positive and significant influence on performance (Path P4), the influence of direct work motivation on performance by involving OCB variables got significant results (path P3.c "0.121"), while the influence of direct work motivation on performance without involving OCB variables got significant results (path P1.c " 0.335 "), with a larger path coefficient 
value. That is, the mediating nature of $\mathrm{OCB}$ on the relationship between direct work motivation and performance is a partial mediating variable. So, it can be concluded that hypothesis 10 is accepted.

\section{Conclusions}

Based on the results of research and analysis on the KPP Pratama Jakarta Kalideres, the following conclusions can be drawn: (1) Organizational commitment has a positive and significant influence on OCB, so it can be concluded that hypothesis 1 is accepted; (2) Transformational leadership has a positive and significant influence on OCB, so it can be concluded that hypothesis 2 is accepted; (3) Work motivation has a positive and significant influence on OCB, so it can be concluded that hypothesis 3 is accepted; (4) Organizational Commitment has a positive and significant influence on performance, so it can be concluded that hypothesis 4 is accepted; (5) Transformational leadership has a positive and significant influence on performance, so it can be concluded that hypothesis 5 is accepted; (6) Work motivation has a positive and significant influence on performance, so it can be concluded that hypothesis 6 is accepted; (7) OCB has a positive and significant influence on performance, so it can be concluded that hypothesis 7 is accepted; (8) Mediation from OCB to the relationship between direct organizational commitment to performance is a partial mediating variable, so it can be concluded that hypothesis 8 is accepted; (9) Mediation from OCB to the relationship between direct transformational leadership on performance is a partial mediation variable, so it can be concluded that hypothesis 9 is accepted; (10) Mediation from OCB to the relationship between direct work motivation and performance is a partial mediation variable, so it can be concluded that hypothesis 10 is accepted.

Based on the results of research and analysis on the KPP Pratama Jakarta Kalideres, the following recommendation can be drawn: (1) Organizational Commitment. For employees, they feel they have an obligation to stay in the organization, one of which can be done by periodically holding a Corporate Value Internalization (ICV) in order to instill organizational values; (2) Leadership Transformational. To build attitudes that will make employees feel confident in their leaders. This can be done by holding in-house training, regular briefings at certain times and family gatherings to increase a sense of togetherness and better communication with employees and their families; (3) Motivation. The leader feels the need to provide and inform clearly about the targets that must be achieved from the level of each individual and provide opportunities for employees to develop themselves and achieve in the organization (DJP); (4) OCB. Leaders need to remind employees to be willing to do what is not part of formal work obligations but supports the influence functioning of the organization. Work according to organizational goals through the office (KPP Pratama Jakarta Kalideres), by providing full support to employees for the achievement of organizational goals (DJP); (5) Performance. Leaders need to provide understanding for all employees that the performance of the institution is the work of all employees of KPP Pratama Jakarta Kalideres. Commitment to the organization, transformational leaders, strong work motivation from employees and OCB employees both to agencies, especially the organization will support the achievement of organizational goals.

\section{References}

[1] B. M. A.-G. Amena Y. Mutahar, Amran MD Rasli, "Relationship of Transformational Leadership, Organizational Learning and Organizational Performance,” Int. J. Econ. Financ., 
vol. 5, no. Special Issue, pp. 406-411, 2015.

[2] T. Vipraprastha, I. N. Sudja, and A. Yuesti, "The Effect of Transformational Leadership and Organizational Commitment to Employee Performance with Citizenship Organization (OCB) Behavior as Intervening Variables (At PT Sarana Arga Gemeh Amerta in Denpasar City),” Int. J. Contemp. Res. Rev., vol. 9, no. 02, pp. 20503-20518, 2018, doi: $10.15520 /$ ijcrr/2018/9/02/435.

[3] M. dan Havidz, "Jurnal SWOT , Volume VII , No 2 , Mei 2017 Jurnal SWOT , Volume VII , No 2 , Mei 2017," Pengaruh Pengemb. Karir, Kompensasi Dan Motiv. Kerja Terhadap Kepuasan Kerja Karyawan Di Pt. Alun Alun Indones. Kreasi, vol. VII, no. 2, pp. 345-357, 2017.

[4] A. Andrew, "Employees' Commitment and Its Impact on Organizational Performance," Asian J. Econ. Bus. Account., vol. 5, no. 2, pp. 1-13, 2017, doi: 10.9734/ajeba/2017/38396.

[5] P. Prabandewi and A. Indrawati, "Pengaruh Kepuasan Kerja, Komitmen Organisasi Dan Gender Terhadap Organizational Citizenship Behavior Di Pt.Bpr Pedungan,” E-Jurnal Manaj. Univ. Udayana, vol. 5, no. 10, p. 255323, 2016.

[6] M. A. Al-Mahasneh, "The impact of Organizational Citizenship Behavior on Job Performance at Greater Amman Municipality,” Eur. J. Bus. Manag., vol. 7, no. 36, pp. 108-118, 2015.

[7] N. South, "an Empirical Study of Performance Management As a Managerial Tool for the Development and Improvement in Employees' Job Performance in Organisation," Aust. J. Bus. Manag. Res., vol. 4, no. 12, pp. 1-n/a, 2015, [Online]. Available: http://search.proquest.com.ezp.waldenulibrary.org/docview/1708473662?accountid $=14872 \% 5$ Cnhttp://sfxhosted.exlibrisgroup.com/waldenu?url ver=Z39.88-

2004\&rft_val_fmt=info:ofi/fmt:kev:mtx:journal\&genre=unknown\&sid=ProQ:ProQ\%3Apqrl\& atitle $=$ AN + EMPIRICAL + STUDY + OF .

[8] P. R. Shankar, A. K. Dubey, N. R. Dwivedi, A. Nandy, and B. Barton, "Knowledge, perception and practice of self-medication among premedical and basic science undergraduate medical students," Asian J. Med. Sci., vol. 7, no. 6, pp. 63-68, 2016, doi: 10.3126/ajms.v7i6.15246.

[9] and H. L. Ghozali, Imam, Partial Least Squares, konsep, teknik dan aplikasi menggunakan program Smartpls 3.0 untuk penelitian empiris. Semarang Badan Penerbit UNDIP, 2017.

[10] M. R. Khan, "The Impact of Organizational Commitment on Employees Job Performance"A Study of Oil and Gas Sector of Pakistan,”, 2016, [Online]. Available: ssrn: https://ssrn.com/abstract $=1570544$.

[11] R. E. E. Lingga, "Pengaruh Kompetensi, Motivas, Dan Disiplin kerja Terhadap Kinerja Pegawai ASN Pda Direktorat Jenderal Pembangunan Daerah Tertinggal.," SWOT Mercu Buana, 2018.

[12] S. Rahmi, Kepemimpinan transformasional dan budaya organisasi Illustrasi dibidang pendidikan. Mitra Wacana Media, 2014

[13] T. Robbins, S. P., \& Judge, Essentials of organizational behavior (Vol. 13). Prentice Hall, 2017.

[14] U. Sekaran and R. Bougie, Research methods for business A skill building approach. John Wiley \& Sons, 2016.

[15] H. Umar, Metode penelitian untuk skripsi dan tesis bisnis Edisi 2. Jakarta: PT RajaGrafindo Persada, 2014.

[16] and D. D. V. F. Yukl, Gary, Theory and research on leadership in organizations Seventh Edition. PT. Indeks. Jakarta., 1992.

[17] https://www.pajak.go.id/id/struktur-organisasi\#

[18] Keputusan Menteri Keuangan Nomor 556/KMK.01/2015 tentang perubahan Keputusan Menteri Keuangan nomor KMK-467/KMK.01/2014 tentang Pengelolaan Kinerja di Lingkungan Kementrian Keuangan

[19] Kemenkeu.go.id: Sejarah Kementerian Keuangan RI di akses 6 Juni 2020

[20] Peraturan Presiden Nomor 28 Tahun 2015 tentang Kementerian Keuangan

[21] Peraturan Pemerintah Nomor 11 Tahun 2017 tentang Manajemen Pegawai Negeri Sipil 
[22] Peraturan Menteri Keuangan Nomor 234/PMK.01/2015 Tentang Organisasi Dan Tata Kerja Kementerian Keuangan

[23] Peraturan Menteri Keuangan Nomor PMK-206.02/PMK.01/2014 tentang Organisasi Dan Tata Kerja Instansi Vertikal DJP 